\title{
IMPLANT-SUPPORTED DISTAL EXTENSION MANDIBULAR PARTIAL OVERDENTURE: COMPARISON OF TWO ATTACHMENT TYPES EFFECT ON MANDIBULAR POSTERIOR RESIDUAL ALVEOLAR BONE (FIVE YEAR RETROSPECTIVE STUDY)
}

\author{
Ehab A. Elsaih*
}

\begin{abstract}
Purpose: This study aimed to compare effect of implant supported removable partial denture (IS RPD) with locator versus ball attachments on mandibular posterior residual alveolar ridge after 5 year period.

Materials and Methods: From available data base of class I partially edentulous mandibular arches modified by bilateral distal implants in 2nd molar region against edentulous maxilla treated with IS RPDs against a maxillary denture. 18 patients were randomly selected and allocated in two equal groups, 9 patient each, as follows; G1, B\&S Group, using a ball and socket attachment and G2, locator group, using locator attachment. The posterior mandibular ridge resorption was evaluated in the form of change in posterior area index ( $\triangle \mathrm{PAI})$ on digital panoramic radiographs over 5 year period. Also the relation of $\triangle \mathrm{PAI}$ to implant marginal bone changes $(\mathrm{MBC})$ and other patient's data as age, edentulous period, prosthesis use period, ridge length, initial ridge height number of relines and attachment maintenance.
\end{abstract}

Results: locator significantly reduce the $\triangle \mathrm{PAI}(0.032)$ compared to B\&S (0.064) with nonsignificant difference in MBC of distal implants.

Conclusion: The IS RPD using locator attachments offer better mandibular posterior ridge preservation versus the $\mathrm{B} \& \mathrm{~S}$ attachment. Carful follow-up and proper post insertion service help to avoid any harmful effect on implant and/or residual ridge, maintaining the prosthesis/attachment/ tissue relation to assure proper functional load distribution.

KEYWORDS: Removable partial denture, dental implant, residual ridge resorption. Locator versus ball attachment

* Associate Professor of Removable Prosthodontics, Department of Removable Prosthodontics, Faculty of Dentistry, Mansoura University. 


\section{INTRODUCTION}

A well-planned, well-constructed removable partial denture (RPD) considered an adequate treatment option for patient with partially edentulous arches ${ }^{[1,2]}$. In distal extension cases, the prosthesis has a hybrid support of teeth via periodontal ligament (PL) and mucosa covering residual alveolar ridge $^{[3]}$. Failure to control the mismatch of tissue resiliency between PL and mucosa creates a series of destructive events that affects the prognosis of abutments, resorption of residual ridge and serviceability of RPD ${ }^{[4-7]}$. Some of the stem causes of distal extension RPD failure were related to poor design ${ }^{[8-14]}$.

Trials to include implants with RPD started in the early 1970s. Since then posterior implants were suggested to resolve this biomechanical dilemma ${ }^{[15-}$ 17]. Since then the use of distal implants in Kennedy class I and II was believed to create a pseudoKennedy class III ${ }^{[16-22]}$. This treatment modality was reported to improve chewing ability, increased patient satisfaction and preserve the integrity of supporting structures ${ }^{[16]}$. Other studies reported increase in maximum muscular function ${ }^{[15,19-22]}$.

The reported complication of this prosthesis includes loosening of screws and healing caps, fracture of acrylic implant attachment housing or fracture of denture base (metal and/or acrylic) ${ }^{[18,23,24]}$. Some studies documented the need for post insertion maintenance within the first 12 months in the form of clasp activation, matrix activation/deactivation/replacement and denture base repair ${ }^{[23,25]}$. These complications were linked to the additional forces placed on the anchorage system (matrices) of the prostheses ${ }^{[24,25]}$.

Finite element studies showed no reduction in the tension forces on abutment teeth, while there was a reduction in the support gained from the ridge posteriorly ${ }^{[26-27]}$. Wismeijer et al ${ }^{[28]}$ reported concentration of most masticatory contact areas and increased force distally around implant wherever their location. The use of bilateral balanced occlusion was suggested to provide even force distribution across the prosthesis, however, this is not easily achievable especially when the antagonist arch is fully dentate ${ }^{[29]}$.

Usually the results of in-vitro studies are suggestive and indicative for similar clinical situations rather than objectively reliable. Till now the clinical reports on effect of implant supported RPD on both residual ridge and implants are few, while reports on the effect of different attachments used is nearly lacking.

This study aim to investigate the null hypothesis that using different attachments in implant supported RPD has no effect on radiographic outcome of both implant marginal bone changes (MBC) and posterior ridge area.

\section{MATERIAL AND METHODS}

This work was approved by the local ethics committee, collage of dentistry,Mansoura University and according to their guide lines and conform to the principles laid down in the Declaration of Helsinki (World Medical Assembly, Helsinki, Finland) and its successors.

\section{Patient selection}

Patients with edentulous maxilla opposing mandibular Kennedy class I partially edentulous arches modified by distal implants and previously treated with implant supported, clasp retained RPD were selected for recall in prosthetic department, Mansoura University on bases of availability of standardized documentation, commitment to follow up schedule, oral hygiene assessment and least 5 years' time labs since the prosthesis delivery.

These patients were further filtrated according to the following criteria; 1) symmetrical long edentulous span (at least missing all molars and one premolar) with implant located at $2^{\text {nd }}$ molar region, 2) attachment is either ball and socket $(B \& S)$ or locator, 3) posterior artificial teeth show no loss of contacts nor attrition facets, 3 ) abutment free from carious lesions, periodontal mobility or apparent attachments loss, 4) acceptable oral hygiene and 
normal mucosa (free from local or general stomatitis and inflammatory overgrowth), 5) maxillary ridge free from flappy areas, 6) patient use prosthesis with no aesthetic or functional complains, 7) maintained prosthesis/tissue (hard or soft) relation during stability check, 8) available digital panoramic radiograph software immediately before attachment screwed-in.

Twenty subjects were found to meet the inclusion criteria (11 B\&S attachment and 9 locator attachment). 18 patients were selected to participate in this study 9 in each group. From 11 subject in $\mathrm{B} \& \mathrm{~S}$ group 9 were randomly selected based on alphabetical order of the first name (Fig. 1). Relatively small sample was inspected for effectiveness depending on previous work ${ }^{[30,31]}$.

All patients were asked to sign informed consent and this work was made according to regulations of ethical committee at collage of dentistry, Mansoura University (A2080120).

Clinical characteristics of the selected cases were demonstrated in table 1; Group $1(G 1)$ of 9 patients with ball and socket attachments (Fig. 2) and Group 2 (G2) of 9 patients with locator attachments (Fig. 3) group 2. The clinical characteristics of the selected cases were presented in table 1.

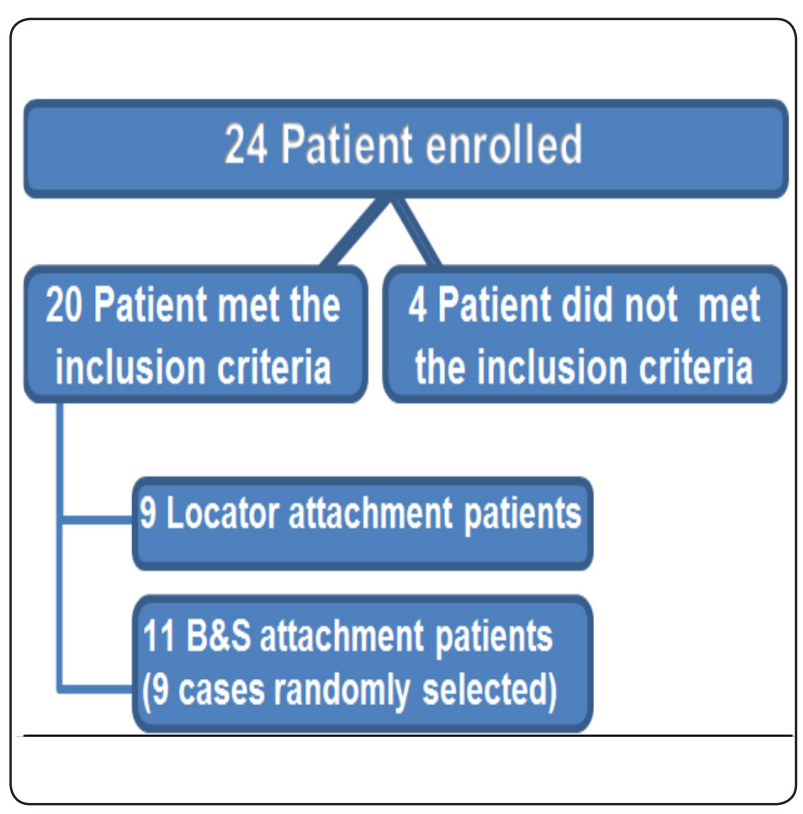

Fig. (1) Flowchart of the patients selection

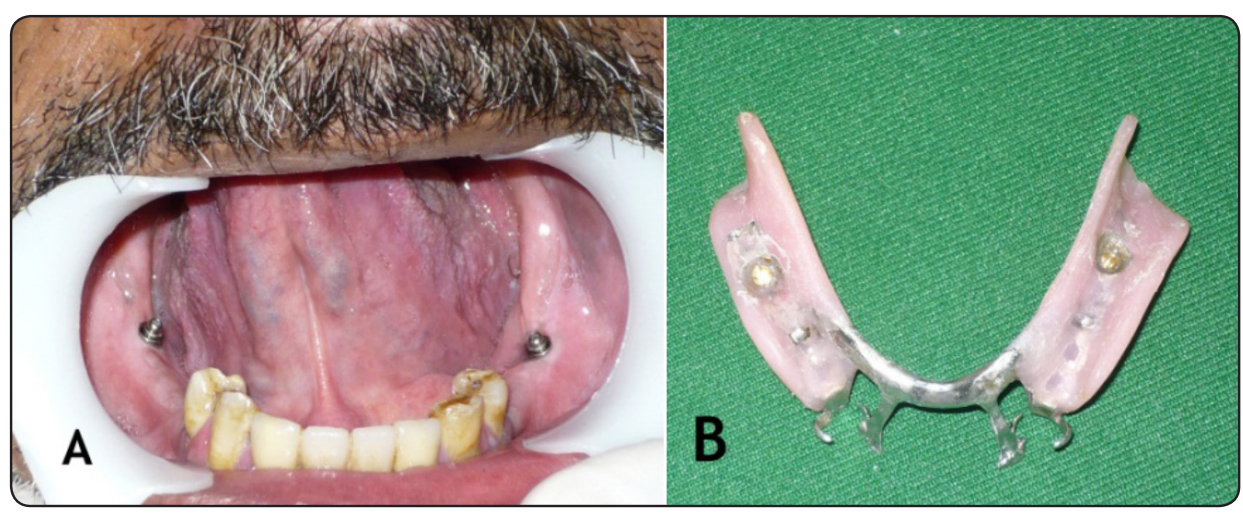

Fig. (2) A) Kennedy class I case modified by posterior implant with ball attachment B) Intaglio-surface of removable partial denture with attachment.

TABLE (1) Show the clinical characteristics of the selected cases.

\begin{tabular}{|c|c|c|c|}
\hline Criteria & Group 1 & Group 2 & All patients \\
\hline Age of patient in years & $52.5 \pm 4$ & $50 \pm 2.5$ & $55 \pm 3$ \\
\hline Time of prosthesis use & $6.7 \pm 0.4$ & $5.9 \pm 0.4$ & $6.3 \pm 0.8$ \\
\hline Gender (male/ female) & $7-2$ & $5-4$ & $13-6$ \\
\hline Clasp retainer (RPA/ RPI) & $2 / 7$ & $3 / 6$ & $5 / 13$ \\
\hline Major connector (bar/plate) & $(8 / 1)$ & $(5 / 4)$ & $13 / 5$ \\
\hline Abutments on implants & Ball \&Socket (Dyna ® smart matrix ) & Locator (tioLogic® Dentaurum) & \\
\hline Implant length (in mm) & $10-12$ & $10-12$ & \\
\hline Implant diameter (n mm) & $3.6-4$ & $3.7-4.2$ & \\
\hline
\end{tabular}




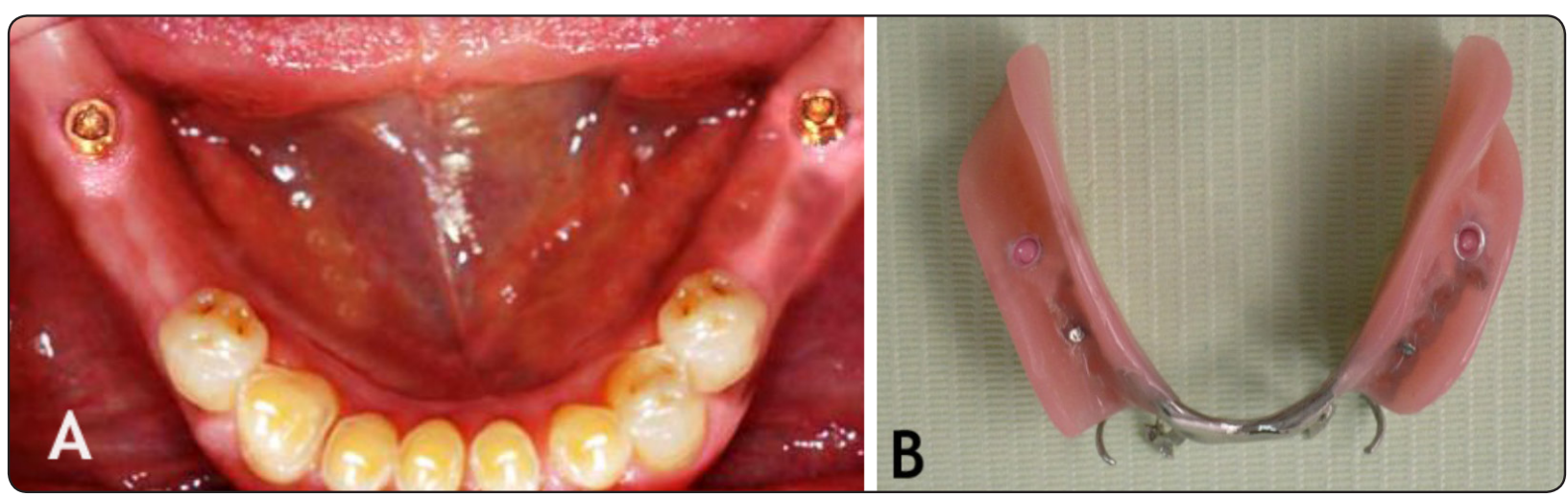

Fig. (3) A) Kennedy class I case modified by posterior implant with locator attachment B) intaglio surface of the removable partial denture with attachment.

\section{Calculating posterior ridge resorption}

A method similar to Wright and Watson ${ }^{[32]}$ was used to calculate the mandibular posterior residual alveolar bone loss over the evaluation period. This method depends on the proportional area measurements in the posterior mandible. All digital panoramic $\mathrm{x}$-ray were traced as follows; MG line connecting the $\mathrm{M}$ point (lower border of mental foramen) and point $\mathrm{G}$ (gonion), SG line connects $\mathrm{G}$ to $\mathrm{S}$ (deepest point of condylar notch), GN line bisecting the MGS angel till the $\mathrm{N}$ point at the bone surface, B point is the first tooth to bone contact of distal abutment, BN line is tracing of the alveolar ridge surface, $\mathrm{N}$ point is dividing GN line 1:2 parts, MǸ line (Fig. 4-a).

Using computer software (AUTOCAD ${ }^{\circledR} 14$ ) the radiographic BNGM area, which represents the posterior alveolar ridge area, is related to MǸG area ,which is based on relatively fixed bony landmarks, the ratio is irrelevant to of radiographic magnification and the mean value of both sides is considered a posterior ridge area index $(\mathrm{PAI})$ for each subject. The change in PAI ( $\triangle$ PAI) over the study period in each group was computed and tabulated.

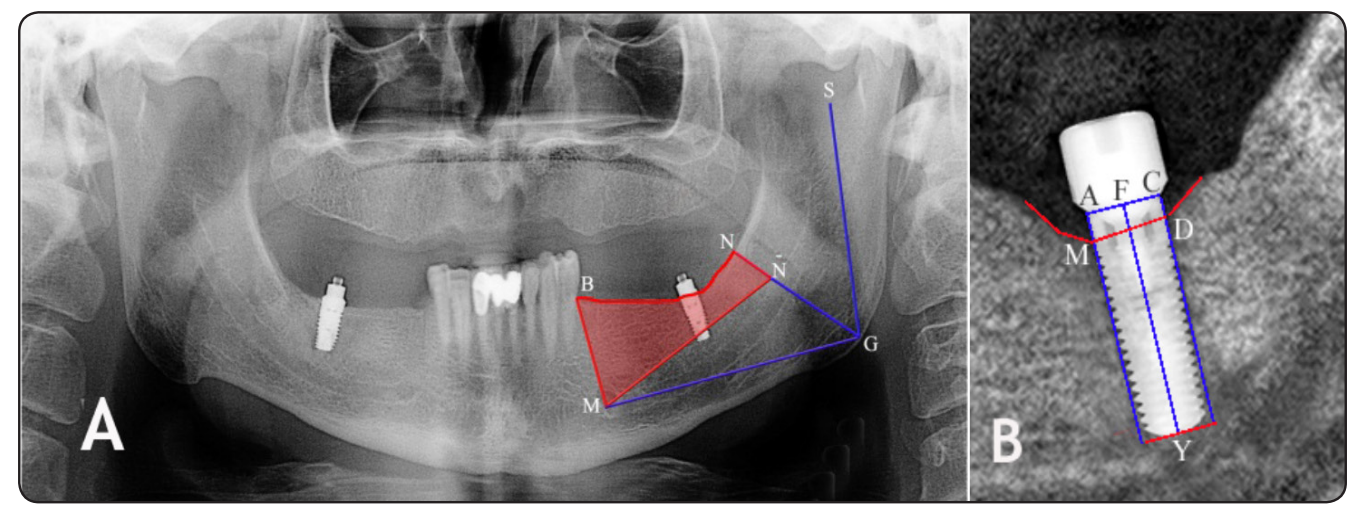

Fig. (4) a) measuring posterior area bone resorption index on panoramic radiograph, 4-b). measuring the mesial and distal marginal bone height changes on radiograph 


\section{Calculating implant marginal bone height changes}

Digital panoramic images $\mathrm{x} 10$ were traced on computer software (CorelDraw ${ }^{\circledR}$ version $10 \mathrm{TM}$, Kodak Digital Science). knowing actual implant length, the magnification error was calculated on each side separately to avoid any image distortion. Implant and its marginal bone was traced as follows; $\mathrm{F}$ is the mid-point on implant shoulder, FY line is the line that bisects the implant, $\mathrm{AC}$ line is the line perpendicular on the FY line across the F point, $\mathrm{AM}$ and $\mathrm{CD}$ lines are the distance between implant collar supra surface and first bone to implant contact in mesial and distal sides respectively (Fig. 4-b). Marginal bone level (MBL) of each patient was calculated from equation $(\mathrm{MBL}=)$. Change in $\mathrm{MBL}$ over 5 year study period (MBC) was calculated and tabulated ${ }^{[33]}$.

\section{Statistical analysis}

Using IBM ${ }^{\circledR}$ SPSS $^{\circledR} 25$ (Statistical Package for Social Science), the descriptive statistics for all variables were extracted, the equality of variances in the samples (homogeneity of variances at level of significance $P>0.05$ ) was verified using Levene's test and the normal distribution were tested with Shapiro-Wilk test at 0.05 level of significance. The inferential statistics made at 0.05 level of significance using independent variable $t$-test for homogenous parametric variables and Mann-Whitney $U$-Test for homogenous non-parametric variables.

Between group comparison of both the main variables ( $\triangle \mathrm{PAI}$ and $\mathrm{MBC}$ ) and the Life data (Age, Edentulous period in years, prosthesis used in years, Ridge length in millimeters, Initial ridge height in millimeters, number of relines and Attachment Activation/ replacement) were made. The correlation between main variables and Life data in each group were verified using Pearson Correlation at 0.05 level of significance.

\section{RESULTS}

The comparison of $\Delta$ PAI for group $1(.064 \pm$ $.0061)$ and group $2(.032 \pm .0042)$ were statistically highly significant. While the comparison of MBC for group 1 ( $1.78 \pm .10 \mathrm{~mm})$ and group $2(1.72 \pm$ $.13 \mathrm{~mm}$ ) were not statistically significant (fig. 5,6) (table. 2).

TABLE (2) Show the descriptive and inferential statistics of the patient's $\triangle \mathrm{PAI}$ and MBC.

\begin{tabular}{ccc}
\hline & $\Delta$ PAI & MBC \\
\hline & Mean \pm SD & Mean \pm SD \\
\hline Group1 & $.064 \pm .0061$ & $1.78 \pm .10$ \\
\hline Group2 & $.032 \pm .0042$ & $1.72 \pm .13$ \\
\hline Independent t-test & $.000 *$ & .083 \\
\hline
\end{tabular}

* significant at the 0.05 level (2-tailed)

Between groups comparisons of age in years, edentulous period in years and initial ridge height in millimeters were significant while between groups comparisons of time of prosthesis used in years and ridge length in millimeters were significant (Table 3, 4). Only in group 1 there was significant correlation between both $\triangle \mathrm{PAI} /$ age and also $\mathrm{MBC} /$ ridge length (Table 5, 6).

TABLE (3) Show the descriptive and inferential statistics of the patient's data.

\begin{tabular}{cccccc}
\hline & Age & $\begin{array}{c}\text { Edentulous period } \\
\text { in years }\end{array}$ & $\begin{array}{c}\text { prosthesis used } \\
\text { in years }\end{array}$ & $\begin{array}{c}\text { Ridge length } \\
(\mathrm{mm})\end{array}$ & $\begin{array}{c}\text { Initial ridge } \\
\text { height }(\mathrm{mm})\end{array}$ \\
\hline & Mean $\pm \mathrm{SD}$ & Mean $\pm \mathrm{SD}$ & Mean $\pm \mathrm{SD}$ & Mean $\pm \mathrm{SD}$ & Mean $\pm \mathrm{SD}$ \\
\hline Group1 & $55.3 \pm 1.6$ & $10.8 \pm .81$ & $6.3 \pm .57$ & $43.0 \pm 1.09$ & $17.0 \pm .62$ \\
\hline Group2 & $51.5 \pm 1.1$ & $8.5 \pm .75$ & $6.2 \pm .51$ & $42.9 \pm 1.17$ & $18.4 \pm .61$ \\
\hline Mann-Whitney $U$-Test & $.000^{*}$ & $.000^{*}$ & .428 & .800 & $.000^{*}$ \\
\hline
\end{tabular}

* significant at the 0.05 level (2-tailed) 
TABLE (4) Show the descriptive and inferential statistics of the denture maintenance (relining and attachment activation/ replacement)

\begin{tabular}{ccc}
\hline & Reline & Attachment Activation/ replacement \\
\hline & Mean (range) & Mean (range) \\
\hline Group1 & $.8750(0-2)$ & $1.37509(0-4)$ \\
\hline Group2 & $.4167(0-1)$ & $1.5833(1-3)$ \\
\hline Mann-Whitney $U$-Test & $.016^{*}$ & 0.352 \\
\hline
\end{tabular}

* significant at the 0.05 level (2-tailed)

TABLE (5) Show the correlation statistics of the patient's MBC and $\triangle$ PAI versus other clinical factors in group 1.

\begin{tabular}{|c|c|c|c|c|c|c|c|c|}
\hline & & \multicolumn{7}{|c|}{ Group factors } \\
\hline Variable & & $\Delta \mathrm{PAI}$ & $\mathrm{MBC}$ & Age & $\begin{array}{l}\text { Edentulous } \\
\text { period }(y)\end{array}$ & $\begin{array}{l}\text { prosthesis } \\
\text { used (y) }\end{array}$ & $\begin{array}{l}\text { Ridge length } \\
\text { (mm) }\end{array}$ & $\begin{array}{l}\text { Initial ridge } \\
\text { height (mm) }\end{array}$ \\
\hline$\Delta \mathrm{PAI}$ & \multirow{2}{*}{$P C(P)$} & 1 & $.130(.544)$ & $.473 *(.020)$ & $-.364-(.080)$ & $-.221-(.299)$ & $-.011-(.958)$ & $-.277-(.190)$ \\
\hline $\mathrm{MBC}$ & & $.130(.544)$ & 1 & $.353(.090)$ & $-.392-(.058)$ & $-.089-(.681)$ & $.407 *(.048)$ & $-.153-(.474)$ \\
\hline
\end{tabular}

$P C=$ Pearson Correlation, $P=$ Significance (2-tailed), *. significant at 0.05 level .

TABLE (6) Show the correlation statistics of the patient's MBC and $\triangle$ PAI versus other clinical factors in group 2.

\begin{tabular}{|c|c|c|c|c|c|c|c|c|}
\hline & & \multicolumn{7}{|c|}{ Group factors } \\
\hline Variable & & $\Delta \mathrm{PAI}$ & $\mathrm{MBC}$ & Age & $\begin{array}{l}\text { Edentulous } \\
\text { period }(\mathrm{y})\end{array}$ & $\begin{array}{l}\text { prosthesis } \\
\text { used (y) }\end{array}$ & $\begin{array}{l}\text { Ridge length } \\
\quad(\mathrm{mm})\end{array}$ & $\begin{array}{l}\text { Initial ridge } \\
\text { height (mm) }\end{array}$ \\
\hline$\Delta \mathrm{PAI}$ & \multirow[t]{2}{*}{$P C(P)$} & 1 & $-.300-(.154)$ & $.062(.772)$ & $-.231-(.278)$ & $-.026-(.902)$ & $.328(.118)$ & $-.051-(.813)$ \\
\hline $\mathrm{MBC}$ & & $-.300-(.154)$ & 1 & $-.045-(.833)$ & $.184(.390)$ & $-.381-(.066)$ & $-.226-(.287)$ & $.047(.827)$ \\
\hline
\end{tabular}

$P C=$ Pearson Correlation, $P=$ Significance (2-tailed), *. significant at 0.05 level.

\section{DISCUSSION}

Distal implant installation change Kennedy class I into modified class III cases thus a new load dynamics frame established. It is claimed to provide a better stability and support with more patient comfort and enhanced masticatory efficiency ${ }^{[15,16,20,22]}$.

All implants were successful over the 5 year study period with a total marginal bone loss of $1.72-1.78 \mathrm{~mm}$ which appear to meet the acceptable range of $1.2 \mathrm{~mm}$ in first year with $0.2 \mathrm{~mm}$ in each year later ${ }^{[34-36]}$.

Biomechanical behavior differ according to the used attachments, in turn the anticipated clinical outcome, the B\&S provide retention and stability without planned support function due to either the innate geometrical design deprived of positive vertical contact or the use of spacers during pickups ${ }^{[31]}$, while the locator provides retention, support and share to less extent in stability due to lower profile than B\&S. 
$\mathrm{MBC}$ values for $\mathrm{B} \& \mathrm{~S}$ group is more than locator group without statistical significance. It appears that both attachments transmits stresses to peri-implant bone in different mechanism but with nearly equal outcome. According to Nissan et al ${ }^{[37]}$, ball transmit more stress to peri-implant marginal bone due to more abutment/ implant ratio.

And according to Mericske-Stern $\mathrm{R}^{[38]}$, the stability function of $\mathrm{B} \& \mathrm{~S}$ provide more stress in bone in functional side. The applied non-axial loading elicit a more dynamic remodeling of the surrounding cortical and especially trabecular bone tissue ${ }^{[39]}$.

On the other side, locator has a dual retention (inner and outer) while $\mathrm{B} \& \mathrm{~S}$ has a single retention (outer), this makes ball attachment transfers less stress than the Locator ${ }^{[40]}$.

In the same time, the lower the attachment profile (i.e. locator), the more Freedom of rotation and the less stress on peri-implant bone ${ }^{[4]}$.

Locator positive share in support change the nature of distal extension RPD thus reduce and control occlusal loads transmitted to distal alveolar bone and according to Shaarawy and Aboelross ${ }^{[42]}$ presence of distal implants in the $1^{\text {st }}$ molar area maximize the role of implants regarding their share in support and minimize that of soft-tissue support posteriorly reduce bone resorption.

Absence of statistical significance between groups in MBC based on attachment type agree with Yuan et al ${ }^{[43]}$, they reported that the clinical studies mostly has shown neutral or no significant differences between attachment systems while in vitro studies more likely to report positive outcomes than clinical and animal studies based on their physical properties and mechanical behavior.

Despite the non-significant difference in MBC between groups, there was a significant difference in $\triangle$ PAI. Thus the change of attachment affect ridge bone distinct of peri-implant bone and this independency between both is shown in terms of non-significant correlation. Also De Jong et al. $2010{ }^{[44]}$ found no correlation between mandibular posterior residual ridge resorption and peri-implant marginal bone loss. Based on the results, the locator positive share in support contrary to $B \& S$ may be the cause of significant $\triangle \mathrm{PAI}$ values reduction.

No relation found between each group factors (edentulous period, period of prosthesis used and Initial ridge height) and either $\mathrm{MBC}$ or $\triangle \mathrm{PAI}$. In agreement with De Jong et al. $2010^{[44]}$, they reported that, The confounding factors of marginal bone loss around the implants, age, gender, initial mandibular height, and the number of years the patient had been edentulous failed to show a significant effect on posterior ridge resorption.

While in $\mathrm{B} \& \mathrm{~S}$ group, a significant correlation was found between $\triangle \mathrm{PAI}$ and age as well as between $\mathrm{MBC}$ and ridge length which may be a reflect of relative high profile compared to locator and according to Ebadian et al $2014^{[41]}$ the reduction in attachment height reduced stress in peri-implant bone.

The number of relines needed in B\&S group significantly more than locator group. The later has a rate of attachment change exceeds the activation of the metal sockets of the former which indicate transmitting of occlusal loads more to ridge in B\&S group and cushion effect offered by plastic components of locator. Which is in accordance to Cakarer et al ${ }^{[45]}$, the locator system showed superior clinical results than the ball attachment, with regard to the rate of prosthodontic complications and the maintenance of the oral function.

Reported $\triangle \mathrm{PAI}$ value range is $0.11-0.14$ for conventional complete denture and 0.05-0.07 for two implant overdenture ${ }^{[3,33-35]}$. Current study range was $0.032-0.064$ with a range of $1.7 \%$ $(0.34 \%$ per year) and $3.4 \%$ ( $0.6 \%$ per year) for locator and $\mathrm{B} \& \mathrm{~S}$ groups respectively. Thus despite the logic role of implant to protect posterior ridge overloading in implant supported RPDs, the 
presence of positive $\triangle \mathrm{PAI}$ indicates actual share of ridge in support. This results agree with ELsyad \& Habib ${ }^{[31]}$, they reported $\triangle$ PAI of $0.073 \pm 0.044$ for $\mathrm{B} \& \mathrm{~S}$ group over 5 years period and pointed out ridge share in support. On the other hand it is lower than the $1.02 \%$ per year of posterior ridge resorption reported by Raedel and associates ${ }^{[46]}$ for bar retained overdenture which suggests the positive impact of posterior implant attachment in the limitation and control of functional loads transmitted to posterior alveolar ridge in addition to significant superiority of locator. Consequently, ridge do share rather bear the load beyond its physiologic tolerance taking in consideration the length of edentulous area and location of implants. This share is pointed out by the study of Rodrigues and associates ${ }^{[47]}$.

Continuous residual ridge resorption is assumptive, multifactorial, ongoing, irreversible biological process, but sharp out line to residual ridge resorption rate is till now not established and the rate is only comparable with care to groups of same categories of edentulousness ${ }^{[48,49]}$.

The posterior ridge resorption in implant supported RPD seems low but to plan for prognostic success clinicians should establish and maintain properly functioning attachment through preserving proper prosthesis/ridge relation by careful monitoring for the need for relining. locator group show significant less relines in addition to its superiority in limited inter-arch situations.

In comparison to conventional RPD, the alveolar bone preservation in implant supported RPDs may be attributed to attachments acting as stabilizer that ,according to Uçtaşli et al ${ }^{[50]}$, prevents the denture settling posteriorly and the current study showed the significant action of locator in reducing ridge resorption. Also estimating of ridge bone resorption after 2.3-4.5 years of last extraction preclude the effect of recent extraction which is connected with a higher rate of bone resorption ${ }^{[51]}$.

\section{CONCLUSION}

For implant supported RPDs the posterior ridge withstand a share of masticatory loads and within the context; the locator seems of more preservation to posterior ridge resorption compared to $\mathrm{B} \& \mathrm{~S}$, but both attachments provides the posterior ridge with a protection of posterior ridge from direct functional loading and consequently decrease rate of predicted, inevitable resorption. For attachments to function correctly the proper prosthesis/tissue relation should be monitored for need of relines.

\section{REFERENCES}

1. Kapur KK. Veterans administration cooperative dental implant study-comparisons between fixed partial dentures supported by blade-vent implants and removable partial dentures-part IV: comparisons of patient satisfaction between two treatment modalities. J Prosthet Dent 1991; 66:517-30.

2. Rissin L, Feldman RS, Kapur KK, Chauncey HH. Six year report of the periodontal health of fixed and removable partial denture abutment teeth. J Prosthet Dent 1985;54:461-7.

3. Bural C. Biomechanics of Removable Partial Dentures. In Removable Partial Dentures. Springer International Publishing; 2016, p.125-35.

4. Monteith BD. Management of loading forces on mandibular distal-extension prostheses - part I: evaluation of concepts for design. J Prosthet Dent 1984;52: 673-81.

5. Watt DM, MacGregor AR. Designing Partial Dentures, Bristol, UK: Wright; 1984, p.41-8.

6. Witter DJ, Haan A, Käyser AF, Rossum G. A 6-year followup study of oral function in shortened dental arches. Part II: Craniomandibular dysfunction and oral comfort. J Oral Rehabil 1994; 21: 353-66.

7. Brudvik JS. Advanced Removable Partial Dentures, Chicago, USA: Quintessence;1999: 127-35.

8. Gapido CG, Kobayashi H, Miyakawa O, Kohno S. Fatigue resistance of cast occlusal rests using $\mathrm{Co}-\mathrm{Cr}$ and $\mathrm{Ag}-\mathrm{Pd}$ Cu-Au alloys. J Prosthet Dent 2003; 90: 261-9.

9. Vallittu PK, Kokkonen M. Deflection fatigue of cobaltchromium, titanium, and gold alloy cast denture clasp. J Prosthet Dent 1995;74:412-9.

10. Craig R, Powers J. Restorative Dental Materials ,St. Louis, USA: Mosby; 2002. 
11. Iwama CY, Preston JD. Cobalt-chromium-titanium alloy for removable partial dentures. Int J Prosthodont 1997;10:309-17.

12. Ben-Ur Z, Matalon S, Aviv I, Cardash HS. Rigidity of major connectors when subjected to bending and torsion forces J Prosthet Dent 1989;62:557-62.

13. Lewis AJ. Failure of removable partial denture castings during service. J Prosthet Dent 1978;39:147-9.

14. Vermeulen AHBM, Keltjens HMAM, Van't Hof MA, Kayser AF. Ten-year evaluation of removable partial dentures: survival rates based on retreatment, not wearing and replacement. J Prosthet Dent 1996;76:267-72.

15. Bakke M, Holm B, Gotfredsen K. Masticatory function and patient satisfaction with implant-supported mandibular overdentures: a prospective 5-year study. Int J Prosthodont 2002;15:575-81.

16. Mijiritsky E, Ormianer Z, Klinger A, Mardinger O. Use of dental implants to improve unfavorable removable partial denture design. Compend Contin Educ Dent 2005;26:744 6.

17. Fields JrH, Campfield Jr RW. Removable partial prosthesis partially supported by an endosseous blade implant. J Prosthet Dent 1974;31: 273-8.

18. Grossmann Y, Nissan J, Levin L. Clinical effectiveness of implant-supported removable partial dentures - a review of the literature and retrospective case evaluation. JOMS 2009;67:1941-6.

19. Wismeijer D, Tawse Smith A, Payne AG. Multicentre prospective evaluation of implant-assisted mandibular bilateral distal extension removable partial dentures: Patient satisfaction. Clin Oral Implants Res 2013;24:20-7.

20. Ohkubo C, Kobayashi M, Suzuki Y, Hosoi T. Effect of implant support on distal-extension removable partial dentures: In vivo assessment. Int $\mathbf{J}$ Oral Maxillofac Implants 2008;23:1095-101.

21. Van Kampen FMC, Van Der Bilt A, Cune MS, Bosman F. The influence of various attachment types in mandibular implant-retained overdentures on maximum bite force and EMG. J Dent Res 2002; 81:170-3.

22. Miyaura K, Morita M, Matsuka Y, Yamashita A, Watanabe T. Rehabilitation of biting abilities in patients with different types of dental prostheses. J Oral Rehabil 2000; 27: 1073-6.

23. Zancopé K, Abrão GM, Karam FK, Neves FD. Placement of a distal implant to convert a mandibular removable Kennedy class I to an implant-supported partial removable Class III dental prosthesis: A systematic review. J Prosthet Dent 2015;113: 528-33.
24. Kaufmann R, Friedli M, Hug S, Mericske-Stern R. Removable dentures with implant support in strategic positions followed for up to 8 years. Int $\mathrm{J}$ Prosthodont 2009;22:233-41.

25. Shahmiri R, Das R, Aarts JM, Bennani V. Finite element analysis of an implant-assisted removable partial denture during bilateral loading: Occlusal rests position. J Prosthet Dent 2014;112:1126-33.

26. Verri FR, Pellizzer EP, Rocha EP, Pereira JA. Influence of length and diameter of implants associated with distal extension removable partial dentures. Implant Dent 2007; 16:270-80.

27. Ohkubo C, Kurihara D, Shimpo H, Suzuki Y, Kokubo Y, Hosoi T. Effect of implant support on distal extension removable partial dentures: in vitro assessment. J Oral Rehabil 2007;34:52-6.

28. Wismeijer D, van Waas M A, Kalk W. Factors to consider in selecting an occlusal concept for patients with implants in the edentulous mandible. The J Prosthet Dent 1995; 74:380-4.

29. Cunha LDAP, Pellizzer EP, Verri FR, Pereira JA. Evaluation of the influence of location of osseointegrated implants associated with mandibular removable partial dentures. Implant Dent 2008;17:278-87.

30. Cohen J. Statistical power analysis for the behavior sciences (Rev. ed.). Hillsdale, NJ: Lawrence Erlbaum Assoc. pp. 1987: 54-55.

31. Elsyad MA, Al-Mahdy YF, Fouad MM. Marginal bone loss adjacent to conventional and immediate loaded two implants supporting a ball-retained mandibular overdenture: a 3-year randomized clinical trial. Clin Oral Implants Res 2012;23:496-503.

32. Wright PS, Watson RM. Effect of prefabricated bar design with implant-stabilized prostheses on ridge resorption. Int J Oral Maxillofac Implants 1998;13:77-81.

33. Urban T, Kostopoulos L, Wenzel A. Immediate implant placement in molar regions: a 12-month prospective, randomized follow-up study. Clin Oral Implants Res 2012;23:1389-97

34. $\mathrm{N}$ von Wowern et al. Implant-supported Overdentures, a Prevention of Bone Loss in Edentulous Mandibles? A 5-year Follow-Up Study. Clin Oral Implants Res 12 (1), 19-25. Feb 2001.

35. Naert I, Gizani S, van Steenberghe D. Bone behavior around sleeping and non-sleeping implants retaining a mandibular hinging overdenture. Clin Oral Implants Res 1999;10:149-54. 
36. Oetterli, M, Kiener P, Mericske-Stern, R. A longitudinal study on mandibular implants supporting an overdenture: the influence of retention mechanism and anatomic-prosthetic variables on periimplant parameters. Int J Prosthodont 2001;14:536-42.

37. Nissan J, Ghelfan O, Gross O, Priel I, Gross M, Chaushu G. The effect of crown/implant ratio and crown height space on stress distribution in unsplinted implant supporting restorations. J Oral Maxillofac Surg 2011;69:1934-9

38. Mericske-Stern R. Three-dimensional force measurements with mandibular overdentures connected to implants by ball-shaped retentive anchors. A clinical study. Int J Oral Maxillofac Implants 1998;13:36-43.

39. Barbier L, Schepers E. Adaptive bone remodeling around oral implants under axial and nonaxial loading conditions in the dog mandible. International Journal of Oral \& Maxillofacial Implants. Int J Oral Maxillofac Implants 1997;12:215-23.

40. Ebadian B, Talebi S, Khodaeian N, Farzin M. Stress analysis of mandibular implant-retained overdenture with independent attachment system: effect of restoration space and attachment height. Gen Dent 2015;63:61-7.

41. Chen IC, Brudvik JS, Mancl LA, Rubenstein JE, Chitswe K, Raigrodski AJ. Freedom of rotation of selected overdenture attachments: an in vitro study. J Prosthet Dent 2011;106:78-86.

42. Shaarawy MA, Aboelross EM. The effect of varying implant position in immediately loaded implant-supported mandibular overdentures. J Oral Implantol 2013;39:345-54

43. Yuan JC, Shyamsunder N, Barao VA, Lee DJ, Sukotjo C. Publication bias in five dental implant journals: an observation from 2005 to 2009. Int J Oral Maxillofac Implants 2011;26:1024-32.
44. De Jong MH, Wright PS, Meijer HJ, Tymstra N. Posterior mandibular residual ridge resorption in patients with overdentures supported by two or four endosseous implants in a 10-year prospective comparative study. Int J Oral Maxillofac Implants 2010;25:1168-74.

45. Cakarer S, Can T, Yaltirik M, Keskin C. Complications associated with the ball, bar and Locator attachments for implant-supported overdentures. Med Oral Patol Oral Cir Bucal 2011;16:953-9.

46. Raedel M, Lazarek-Scholz K, Marré B, Boening KW, Walter MH. Posterior alveolar ridge resorption in bar-retained mandibular overdentures: 10-year results of a prospective clinical trial. Clin Oral Implants Res 2015;26:1397-401

47. Rodrigues RCS, Faria ACL, Macedo AP, de Mattos MDGC, Ribeiro RF. Retention and stress distribution in distal extension removable partial dentures with and without implant association. J Prosthodont Res 2013;57: 24-9.

48. Ehab AE Elsaih. Effect of different mandibular prosthesis on anterior maxillary ridge resorption (retrospective study). Egypt Dent 2015;61: 131-8.

49. Malchiodi L, Moro T, Cattina DP, Cucchi A, Ghensi P, Nocini PF. Implant rehabilitation of the edentulous jaws: Does tilting of posterior implants at an angle greater than $45^{\circ}$ affect bone resorption and implant success?: A retrospective study. Clin Implant Dent Relat Res. 2018;20(5):867-874.

50. Uçtaşli S1, Hasanreisoğlu U, Işeri H. Cephalometric evaluation of maxillary complete, mandibular fixed-removable partial prosthesis: a 5-year longitudinal study. J Oral Rehabil 1997;24:164-9.

51. Tallgren A, Lang BR, Walker GF, Ash MM Jr. Roentgen cephalometric analysis of ridge resorption and changes in jaw and occlusal relationships in immediate complete denture wearers. J Oral Rehabil 1980;7:77-94. 